Indonesian Journal of Pharmaceutical Science and Technology Journal Homepage : http://jurnal.unpad.ac.id/ijpst/

UNPAD

\title{
Isolation and Characterization of Physicochemical Properties of Mucilago Gedi Leaf (Abelmoschus manihot L. Medik)
}

\author{
Elvie Rindengan*, Marline Abdassah, Anis Y. Chaerunisaa
}

Faculty of Pharmacy, Universitas Padjadjaran, Jatinangor, Indonesia

Submitted 12 May 2018; Revised 29 June 2018; Accepted 1 July 2018; Published 1 October 2018

*Corresponding author: elvie.rindengan@gmail.com

\begin{abstract}
The aim of this research was to isolate the mucilage from gedi leaf (Abelmoschus manihot L. Medik) and to characterize the physicochemical properties. The isolation result was yellowish brown powder that swells and dissolves slowly in water, but does not dissolve in ethanol, methanol, acetone and ether. The yield was $1.33 \%$. Swelling index value was $100 \%$ and viscosity was $28 \pm 2.65$ mpas, $\mathrm{pH} 7.1$. Proximate analysis showed $10.46 \%$ of water content, $38.80 \%$ of ash, $14.66 \%$ of protein, $0.69 \%$ of fat, $35.38 \%$ of carbohydrate. Water holding capacity (WHC) and oil holding capacity (OHC) of mucilage were respectively $4.23 \pm 0.18$ and $0.65 \pm 0.14$. Viscosity, Swelling index, WHC and OHC of mucilage from gedi leaf might be considered as pharmaceutical excipients.
\end{abstract}

Keywords: Abelmoschus manihot, mucilage, swelling, viscosity

\section{Isolasi dan Karakterisasi Sifat Fisikokimia Musilago Daun Gedi (Abelmoschus Manihot L. Medik)}

\begin{abstract}
Abstrak
Penelitian ini bertujuan untuk mengisolasi musilago daun gedi (Abelmoschus manihot L. Medik) dan karakterisasi sifat fisikokimianya. Hasil isolasi berupa serbuk berwarna coklat kekuningan yang mengembang dan larut perlahan dalam air, tapi tidak larut dalam etanol, metanol, aseton dan eter. Rendemen yang diperoleh 1,33\%. Nilai sweling index $100 \%$ dan viskositas $28 \pm 2,65 \mathrm{mpas}, \mathrm{pH}$ 7,1. Analisis proksimat menunjukkan kadar air $10,46 \%$, abu $38,80 \%$, protein $14,66 \%$, lemak $0,69 \%$, karbohidrat 35,38\%. Water holding capacity (WHC) dan oil holding capacity (OHC) dari musilago masing-masing 4,23 $\pm 0,18$ dan 0,65 $\pm 0,14$. Viskositas, swelling index, WHC dan OHC dari serbuk musilago gedi dapat menjadi pertimbangan dalam penggunaannya sebagai eksipien sediaan farmasi.
\end{abstract}

Kata Kunci: Abelmoschus manihot, musilago, swelling, viskositas 


\section{Pendahuluan}

Musilago adalah hidrokoloid tumbuhan, merupakan monosakarida atau campuran monosakarida dan asam uronat dan pada hidrolisis menghasilkan campuran gula dan asam uronat. Musilago umumnya adalah produk normal metabolisme yang terbentuk di dalam sel (formasi intraselular) dan sering ditemukan di sel epidermis daun, dalam mantel biji, akar dan kulit kayu. Musilago tidak larut dalam alkohol tapi larut atau mengembang dalam air. ${ }^{1}$ Gom dan musilago mengandung molekul hidrofilik, yang dengan air membentuk larutan kental atau gel. Sifat senyawa yang ada mempengaruhi sifat gom dan musilago yang berbeda. Keuntungan gom dan musilago dari bahan alam antara lain, biodegradable, biocompatible, tidak beracun, murah, mudah diperoleh, dan sebagian besar diperoleh dari sumber yang dapat dimakan. ${ }^{2}$

Musilago dari tanaman telah diteliti penggunaannya sebagai pengikat, penghancur, pengental dalam sediaan oral, pensuspensi, pengemulsi, mucoadhesive, sustained release matrix, penyalut, periodontal film, dan basis gel untuk penggunaan topikal. ${ }^{3}$

Abelmoschus manihot L. Medik merupakan tumbuhan dari keluarga Malvaceae. Tanaman ini dikenal dengan nama Gedi, yang oleh masyarakat di Sulawesi digunakan sebagai sayuran. Daun gedi mempunyai aktivitas antioksidan dengan adanya kandungan total flavonoid dan total fenol yang tinggi ${ }^{4}$ dan dapat meningkatkan kepadatan tulang. ${ }^{5}$ Daun Gedi mempunyai kandungan lendir atau musilago. Musilago yang dihasilkan pada saat dimasak sama dengan yang dihasilkan oleh buah Okra (Abelmoschus esculentus). ${ }^{6} \quad$ Polisakarida dalam mucilago gedi mengandung galaktosa, glukosa, manosa dan sedikit arabinosa. ${ }^{7}$ Penelitian terdahulu menyimpulkan bahwa musilago dari daun gedi dapat digunakan sebagai emulgator dalam pembuatan emulsi.

\section{Metode}

2.1. Alat dan Bahan

Alat yang digunakan dalam penelitian ini, Oven (Memmert), Timbangan Analitik (Mettler Toledo), Vortex Mixer, Sentrifuge, Spektrofotometer Serapan Atom (SSAPerkin Elmer). Bahan yang digunakan dalam penelitian ini adalah daun gedi yang diperoleh dari daerah Tomohon - Sulawesi Utara. Bahan lain yaitu, aqua destilata, alkohol 96\%, natrium metabisulfit, reagen molish, iodin, $\mathrm{HNO}_{3}$, aseton, kloroform, metanol, oleum olivarum.

\subsection{Determinasi Tanaman}

Tanaman gedi yang digunakan dalam penelitian ini diambil dari daerah Tomohon Sulawesi Utara dan telah dideterminasi di Laboratorium Taksonomi Tumbuhan Departemen Biologi FMIPA UNPAD dengan kesimpulan bahwa tanaman yang digunakan adalah Abelmoschus manihot L. Medik.

\subsection{Isolasi Musilago}

Prosedur isolasi daun gedi mengacu kepada beberapa penelitian terdahulu tentang isolasi musilago. Daun gedi dicuci dengan

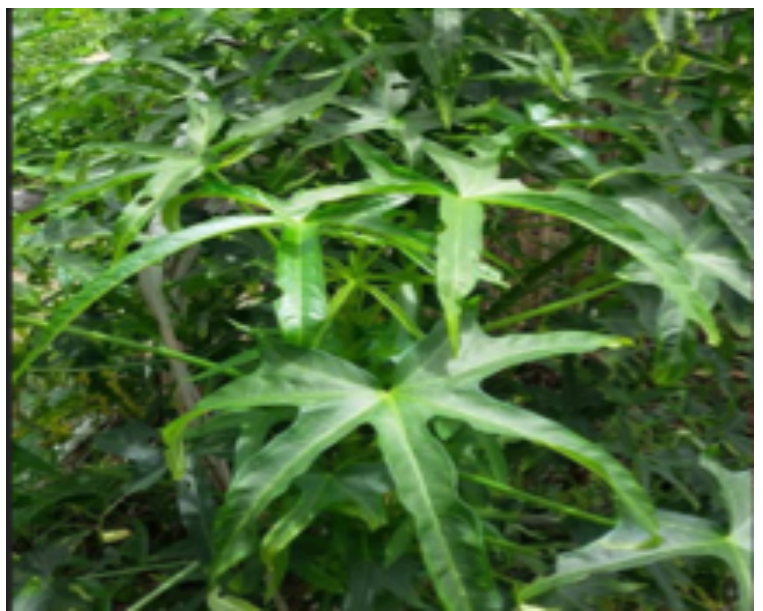

Gambar 1 Daun Gedi (Abelmoschus manihot L. Medik) 


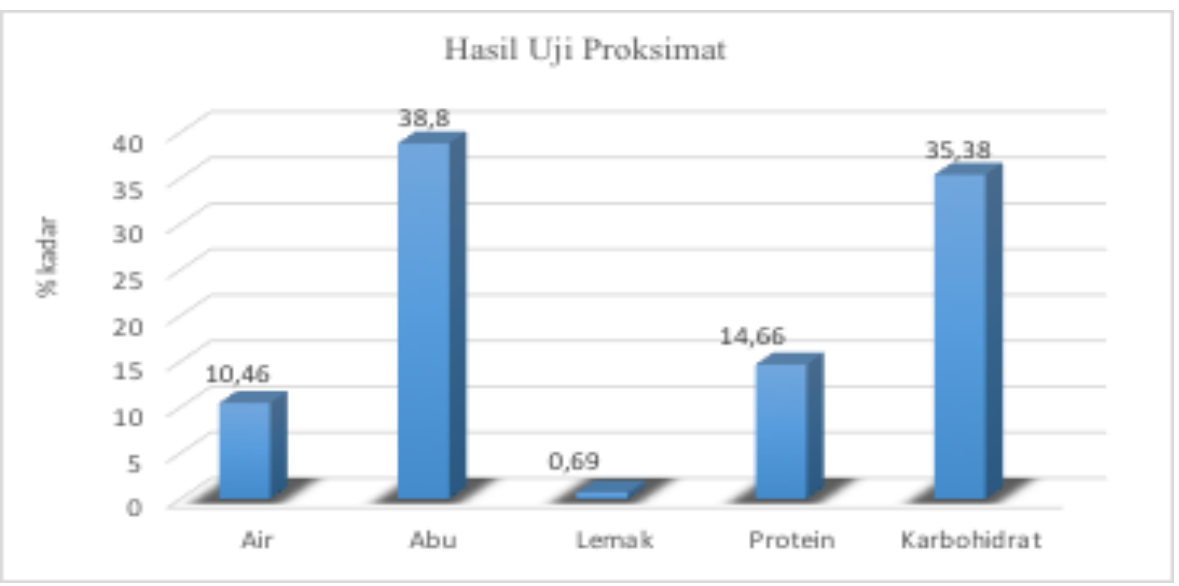

Gambar 2 Hasil Uji Proksimat Musilago Gedi

air mengalir kemudian ditiriskan, setelah itu dipotong kecil-kecil. Daun yang telah dipotong direndam dengan perbandingan 1:5 dalam larutan natrium metabisulfit $1 \%$. Rendaman kemudian dibiarkan selama 24 jam, setelah itu dipanaskan 15-30 menit, dibiarkan selama 1 jam dan disaring. Supernatan kemudian ditambahkan dengan etanol 96\% dengan perbandingkan 1:3 dengan pengadukan. Musilago dipisahkan dan dikeringkan dengan oven pada suhu $50^{\circ} \mathrm{C}$ dan dihaluskan.

Karakterisasi fisikokimia musilago daun gedi yang dilakukan meliputi : organoleptik, \% hasil, uji molish, uji iodin, kelarutan, viskositas, swelling index, laju alir, indeks kompresibilitas, ratio Haussner, uji proksimat, $\mathrm{pH}$, cemaran logam berat, cemaran mikroba, kandungan mineral, water holding capacity dan oil holding capacity.

\section{Hasil}

3.1. Rendemen

Rendemen yang diperoleh dari hasil isolasi dari daun gedi sebesar 1,39\% \pm 0,26 . Serbuk musilago berwarna coklat dan mempunyai bau yang karakteristik.

\subsection{Identifikasi}

Identifikasi sederhana untuk melihat adanya kandungan musilago menurut metode yang dilakukan oleh Yahyaoui menunjukkan hasil isolasi tersebut adalah musilago. ${ }^{8}$ Hasil uji molish positif mengandung karbohidrat dan negatif untuk uji pati dengan larutan iodin.

\subsection{Kelarutan}

Pengujian kelarutan dengan air menunjukkan musilago mengembang dan larut perlahan dalam air. Dengan aseton, kloroform, metanol dan etanol konsentrasi masing-masing $1 \%$ menunjukkan musilago tidak larut.

\subsection{Uji Cemaran Mikroba}

Pengujian cemaran mikroba mengikuti

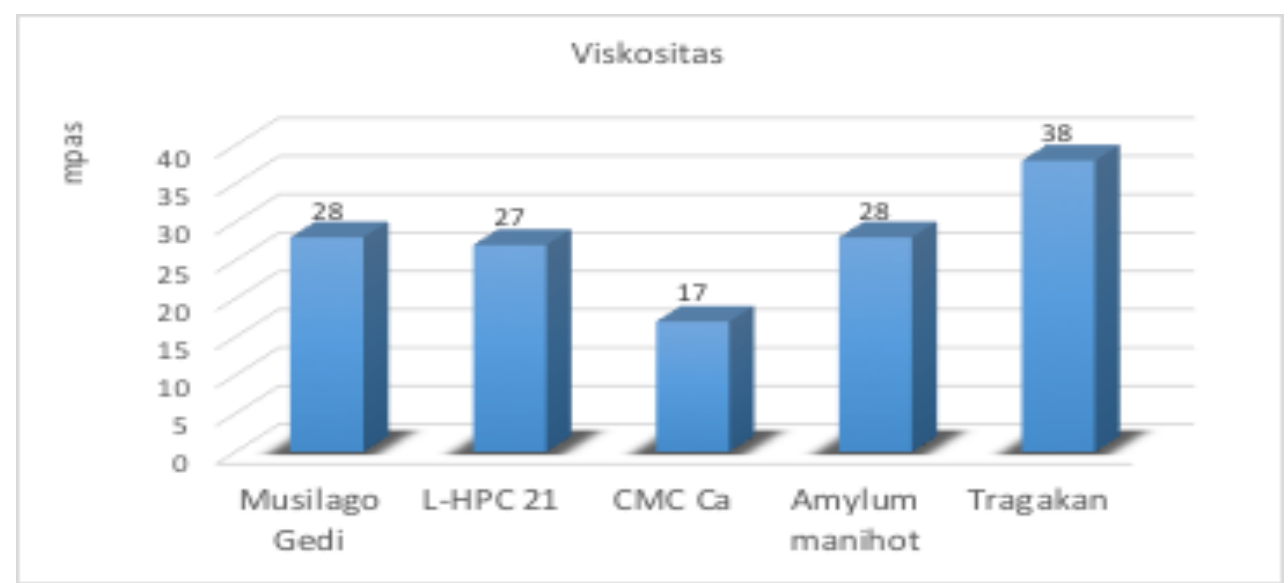

Gambar 3 Hasil Uji Viskositas Musilago Gedi, L-HPC 21, CMC Ca, Amylum manihot dan Tragakan 
Tabel 1 Hasil Pengukuran Cemaran Logam Berat dan Kandungan Mineral

\begin{tabular}{cc}
\hline Logam / Mineral & Kadar \\
\hline $\mathrm{Pb}$ & $5,1474 \mathrm{mg} / \mathrm{kg}$ \\
$\mathrm{Cd}$ & $2,1489 \mathrm{mg} / \mathrm{kg}$ \\
$\mathrm{Sn}$ & $3,6482 \mathrm{mg} / \mathrm{kg}$ \\
$\mathrm{Cu}$ & $11,3546 \mathrm{mg} / \mathrm{kg}$ \\
$\mathrm{Fe}$ & $312,45 \mathrm{mg} / \mathrm{kg}$ \\
$\mathrm{Ca}$ & $22,413 \mathrm{gr} / \mathrm{kg}$ \\
$\mathrm{Na}$ & $49,775 \mathrm{gr} / \mathrm{kg}$ \\
$\mathrm{K}$ & $33,208 \mathrm{gr} / \mathrm{kg}$ \\
$\mathrm{Mg}$ & $14,192 \mathrm{gr} / \mathrm{kg}$ \\
\hline
\end{tabular}

prosedur Total Plate Count (TPC). ${ }^{9}$ Hasil enumerasi menunjukkan nilai TPC adalah $4,66 \times 10^{3}$.

\subsection{Pengukuran $\mathrm{pH}$ dan Uji Viskositas}

Hasil pengukuran $\mathrm{pH}$ dan viskositas dilakukan terhadap dispersi $1 \%(\mathrm{~b} / \mathrm{v})$ serbuk musilago dalam air suling. $\mathrm{pH}$ menunjukkan musilago daun gedi memiliki $\mathrm{pH}$ 7,1. Pengujian viskositas dilakukan juga terhadap L-HPC 21, CMC Ca, amilum manihot dan tragakan menggunakan viskometer Brookfield dengan spindle yang sesuai. Viskositas dari masing-masing bahan dapat dilihat pada Gambar 3.

\subsection{Swelling Index, Water Holding Capacity (WHC) dan Oil Holding Capacity (OHC)}

Pengujian viskositas dilakukan menurut metode yang dilakukan oleh peneliti sebelumnya ${ }^{10,11}$ dengan modifikasi. Hasil pengujian ketiga parameter ini dapat dilihat pada Tabel 2.

\subsection{Laju Alir, Sudut Diam, Indeks} Kompresibilitas dan Ratio Haussner

Serbuk musilago gedi memiliki indeks kompresibilitas 24,67 $\pm 3,09$ dan rasio Haussner 1,33 $\pm 0,05$, dan sudut diam 19,57 $\pm 0,14$ (Tabel 3).

\section{Pembahasan}

Hasil isolasi dari musilago gedi mirip dengan yang diperoleh pada isolasi musilago daun kaktus mawar (Pereskia bleo) yaitu 1,1$2,12 \%{ }^{13}$, dan lebih tinggi dari hasil isolasi musilago buah jaracatiá (Carica quercifolia (A. St. Hil.) Hieron) yaitu 1,19\%. ${ }^{14}$ Perendaman dilakukan selama 24 jam setelah itu dilanjutkan dengan pemanasan dilakukan untuk meningkatkan pelepasan musilago dari daun gedi. Hasil yang diperoleh dengan adanya pemanasan lebih tinggi dibandingkan tanpa adanya proses pemanasan (data tidak ditampilkan). Hal ini sejalan dengan penelitian yang dilakukan oleh Tze Hong and Hayati Ibrahim, menunjukkan bahwa pemanasan dapat meningkatkan jumlah rendemen musilago yang diperoleh. ${ }^{13}$ Warna musilago sangat bergantung dari asal tanaman yang diisolasi karena masing-masing mempunyai unsur penyusun yang berbeda. Warna yang dihasilkan dalam isolasi ini adalah coklat. Hasil isolasi dari buah Coccinia indica berwana coklat ${ }^{10}$, biji Leucaena leucocephala dan Mimosa pudica, berwarna putih. ${ }^{15}$

Pembentukan endapan flokulan pada hasil maserasi suatu tanaman menunjukkan adanya musilago. ${ }^{8}$ Metode ini yang dilakukan pada saat isolasi musilago dari daun gedi. Dengan demikian menunjukkan bahwa hasil isolasi tersebut adalah musilago. Uji molish merupakan uji adanya karbohidrat dan uji

Tabel 2 Hasil Pengukuran Swelling Index, Water Holding Capacity (WHC) dan Oil Holding Capacity $(\mathrm{OHC})$

\begin{tabular}{cc}
\hline Parameter & Hasil \\
\hline Swelling Index & $100 \pm 0 \%$, \\
Water Holding Capacity & $4,23 \pm 0,18$ \\
Oil Holding Capacity & $0,65 \pm 0,14$ \\
\hline
\end{tabular}


Table 3 Laju Alir, Sudut Diam, Indeks Kompresibilitas dan Ratio Haussner

\begin{tabular}{cc}
\hline Parameter & Hasil \\
\hline Laju Alir (detik/100gram) & $1,83 \pm 0,29$ \\
Sudut Diam & $19,57 \pm 0,14$ \\
Bulk Density & $0,71 \pm 0,01$ \\
Tapped Density & $0,94 \pm 0,02$ \\
Indeks Kompresibilitas & $24,67 \pm 3,09$ \\
Rasio Haussner & $1,33 \pm 0,05$ \\
\hline
\end{tabular}

iodin untuk melihat adanya kandungan pati dalam suatu bahan. Terbentuknya cincin ungu menunjukkan hasil positif adanya kandungan karbohidrat musilago gedi. Perubahan warna biru dalam larutan uji dengan meneteskan larutan iodin menunjukkan adanya kandungan pati, dan uji yang dilakukan terhadap musilago gedi tidak terjadi perubahan warna yang artinya tidak adanya kandungan pati.

Syarat cemaran mikroba menurut Handbook of Pharmaceutical Excipient adalah $1000 \mathrm{cfu} / \mathrm{gram} .{ }^{17}$ Hasil pengujian cemaran mikroba musilago gedi belum memenuhi persyaratan. Sehingga perlu dievaluasi lagi prosedur isolasi dan cara penyimpanan sampel yang baik untuk mendapatkan hasil yang memenuhi persyaratan.

Musilago memiliki kandungan karbohidrat, abu dan protein yang tinggi berdasarkan uji proksimat yang dilakukan. Penelitian yang dilakukan oleh Mandey menunjukkan bahwa daun gedi mengandung protein dan mineral kalsium yang tinggi. ${ }^{18}$ Kadar abu musilago gedi lebih tinggi dibandingkan dengan musilago dari Hibiscus rosa-sinensis Linn dan Hibiscus mutabilis Linn ${ }^{19}$ dan sedikit lebih tinggi dari musilago Opuntia spp yaitu $37,3 \% .^{20}$ Kadar abu menunjukkan tingginya kandungan mineral yang terkandung di dalamnya dan dibuktikan juga dengan pengujian kandungan mineral menggunakan Spektofotometer Serapan Atom (SSA) yang menunjukkan mineral yang terkandung dalam musilago cukup tinggi. Kandungan $\mathrm{Ca}$ yang tinggi dalam musilago ini sejalan dengan penelitian sebelumnya bahwa daun gedi (Abelmoschus manihot L. Medik) dapat mengurangi resiko terjadi osteoporosis. $^{5}$ Protein yang tinggi dalam suatu bahan akan mempengaruhi viskositas bahan tersebut. ${ }^{21}$
Viskositas dispersi $1 \%$ musilago gedi $28 \pm 2,65$ mpas. Nilai ini lebih tinggi dibandingkan dengan viskositas musilago Chrysophyllum albidum 20 mpas. ${ }^{22}$ Pengukuran viskositas juga dibandingkan dengan LHPC-21, CMC Ca, amilum manihot dan tragakan. Viskositas 1\% musilago gedi sama dengan amilum manihot dan LHPC21, tapi lebih kecil dibandingkan tragakan. Viskositas merupakan salah satu faktor yang mempengaruhi keefektifan suatu pengikat dalam formula tablet. ${ }^{23}$ Nilai $\mathrm{pH}$ musilago gedi berada pada $\mathrm{pH}$ normal sehingga tidak mengiritasi jika digunakan dalam formula sediaan obat.

Hasil pengujian swelling index yang diperoleh adalah $100 \pm 0 \%$, hasil ini lebih tinggi dibandingkan dengan musilago biji Mimosa pudica yang mempunyai swelling index $81,18 \%,{ }^{16}$ musilago Chrysophyllum albidum 91,70\%, ${ }^{22}$ musilago buah Coccinia indica $81 \% .^{10}$ Swelling merupakan salah satu mekanisme aksi suatu disintegran, pengembangan disintegran menyebabkan tekanan sehingga granul tablet pecah. ${ }^{24}$ Nilai swelling index juga akan mempengaruhi nilai water holding capacity. Nilai WHC dan $\mathrm{OHC}$ dari musilago masing-masing $\quad 4,23 \pm 0,18$ dan $0,65 \pm 0,14$. WHC/OHC sebagai jumlah air/minyak yang diserap per g bahan kering. Musilago mudah terhidrasi karena kapasitas menahan airnya untuk menghasilkan gel atau larutan dengan viskositas yang tinggi pada konsentrasi yang rendah dan sifat ini bergantung pada struktur kimia dari polisakarida tersebut. ${ }^{25,26}$

Serbuk dengan sudut $\leq 30$ memiliki laju alir yang baik. Musilago gedi memiliki laju alir yang baik dengan sudut diam 19,57 dan nilai indeks kompresibilitas yang cukup sedangkan indeks kompresibilitas yang baik 
$\leq 20$ sedangkan rasio Haussner semakin baik jika mendekati angka 1.

\section{Kesimpulan}

Hasil isolasi musilago dari daun gedi telah diuji karakteristik fisikokimianya. Berdasarkan hasil karakterisasi tersebut dapat disimpulkan serbuk musilago gedi dapat dikembangkan sebagai eksipien sediaan farmasi seperti musilago dari tanaman lain yang telah diteliti penggunaannya sebagai ekspien.

\section{Daftar Pustaka}

1. Evans WC. Trease and Evans, Pharmacognosy. Sixteenth. Saunders Elsevier; 2009.

2. Deogade UM, Deshmukh VN, Sakarkar DM. Natural Gums and Mucilage' s in NDDS : Applications and Recent approaches. Int $J$ PharmTech Res. 2012;4(2):799-814.

3. Prajapati VD, Jani GK, Moradiya NG, Randeria NP. Pharmaceutical applications of various natural gums, mucilages and their modified forms. Carbohydr Polym. 2013;92(2):1685-99.

4. Taroreh M, Raharjo S, Hastuti P, Murdiati A. Antioxidative Activities of Various Fractions of Gedi's Leaf Extracts (Abelmoschus Manihot L. Medik). Agric Agric Sci Procedia. 2016;9:271-8.

5. Puel C, Mathey J, Kati-Coulibaly S, Davicco MJ, Lebecque P, Chanteranne B, et al. Preventive effect of Abelmoschus manihot (L.) Medik. on bone loss in the ovariectomised rats. $J$ Ethnopharmacol. 2005;99(1):55-60.

6. Preston SR, Aalbersberg B, Brunt A, Spence N, Dori F, Kambuow R, et al. Aibika/Bele. Abelmoschus manihot (L.) Medik. Roma, Italy: International Plant Genetic Resources Institute; 1998.

7. Wang $\mathrm{X}$, Wang $\mathrm{Y}$, Wu $\mathrm{M}$, Zhang $\mathrm{X}$. Determination of Molecular Weights and Monosaccharide Compositions in Abelmoschus manihot Polysaccharides 1 . Russ J Phys Chem. 2012;86(9):1469-72.

8. Yahyaoui O El, Ouaaziz NAIT, Guinda I, Sammama A. Phytochemical screening and thin layer chromatography of two medicinal plants: Adansonia digitata ( Bombacaceae ) and Acacia raddiana ( Fabaceae ). 2017;6(1):10-5.

9. Badan Standarisasi Nasional. Metode pengujian cemaran mikroba dalam daging, telur dan susu, serta hasil olahannya. Standar Nas Indones. 2008;(SNI 2897:2008).

10. Motiwala MN, Dumore MN, Rokde V V., Bodhe MM, Gupta RA, Dumore NG, et al. Characterization and antioxidant potential of Coccinia indica fruit mucilage: Evaluation of its binding properties. Bioact Carbohydrates Diet Fibre [Internet]. 2015;6(2):69-74.

11. Thanatcha, R. and Pranee A. Extraction and characterization of mucilage in Ziziphus mauritiana Lam. 2008;212:20112.

12. WHO. Quality Control Methods for Herbals Materials. World Health Organization; 1998.

13. Tze Hong N, Hayati Ibrahim N. Extraction And Characterization Of Mucilage From Leaves Of Pereskia bleo (Rose Cactus). J Teknol dan Ind Pangan. 2012;23(2):210 6.

14. Faccio C, Machado RAF, De Souza LM, ZoldanSR, QuadriMGN.Characterization of the mucilage extracted from jaracati (Carica quercifolia (A. St. Hil.) Hieron). Carbohydr Polym. 2015;131:370-6.

15. Deodhar, Paradkar AR, Purohit A. Preliminary evaluation of Leucaena leucocephala seed gum as a tablet binder. Drug Dev Ind Pharm. 1998;24(6):57782.

16. Ahuja M, Kumar A, Yadav P, Singh K. Mimosa pudica seed mucilage: Isolation; characterization and evaluation as tablet disintegrant and binder. Int $J$ Biol Macromol. 2013;57:105-10.

17. Rowe R, Sheskey P, Quinn M. Handbook of Pharmaceutical Excipients. Handb Pharm excipients, Sixth Ed. 2009;

18. Mandey S. Analisis Botani dan Pemanfaatan Antimikroba Daun Gedi (Abelmoschus manihot L. Medik) Sebagai Kandidat Bahan Pakan Ayam Pedaging. 
Lembaga Penelitilian dan Pengabdian Kepada Masyarakat. Manado; 2013.

19. Kassakul W, Praznik W, Viernstein H, Hongwiset D, Phrutivorapongkul A, Leelapornpisid P. Characterization of the mucilages extracted from hibiscus rosasinensis linn and hibiscus mutabilis linn and their skin moisturizing effect. Int $J$ Pharm Pharm Sci. 2014;6(11):453-7.

20. Sepulveda E, Saenz C, Aliaga E, Aceitun. C. Extraction and characterization of mucilage in Opuntia spp. J Arid Environ. 2007;68(1):534-45.

21. Dissanayake Ramchandran, L. and Vasiljevic, T. M. Influence of $\mathrm{pH}$ and protein concentration on rheological properties of whey protein dispersions. Int Food Res J. 2013;20(5):5.

22. Ajala TO, Akin-Ajani OD, IhuomaChidi C, Odeku OA. Chrysophyllum albidum mucilage as a binding agent in paracetamol tablet formulations. J Pharm Investig. 2016;46(6):565-73.

23. Siregar C. Teknologi Farmasi Sediaan Tablet: Dasar - dasar Praktis. Jakarta: EGC; 2010. 204 p.

24. Anwar E. Eksipien dalam Sediaan Farmasi, Karakterisasi dan Aplikasi. Pertama. Jakarta: PT. Dian Rakyat; 2012.

25. Simas-tosin FF, Barraza RR, Petkowicz CLO, Silveira JLM, Sassaki GL, Santos EMR, et al. Food Hydrocolloids Rheological and structural characteristics of peach tree gum exudate. Food Hydrocoll. 2010;24(5):486-93.

26. Whistler RL. Introduction to Industrial Gums. Third Edit. Industrial Gums: Polysaccharides and Their Derivatives: Third Edition. Academic Press, Inc.; 1993. 1-19 p. 